\title{
Hard metal asthma: cross immunological and respiratory reactivity between cobalt and nickel?
}

\author{
T Shirakawa, Y Kusaka, N Fujimura, M Kato, S Heki, K Morimoto
}

\begin{abstract}
Eight asthmatic patients with hard metal asthma due to cobalt underwent bronchial provocation challenge with nickel sulphate. Seven patients developed a fall in $\mathrm{FEV}_{1}$ of $20 \%$ or more after inhaling nickel sulphate, four showing an immediate response and three a late response. Eight control subjects, including six asthmatic patients, with no history of hard metal exposure, showed no bronchoconstriction in response to a provocation challenge with nickel sulphate. Specific antibodies to nickel conjugated human serum albumin were present in four of the eight patients with sensitivity to cobalt conjugated human serum albumin but were absent from the serum of 60 unexposed asthmatic patients and 25 exposed symptom free workers. These results suggest that nickel as well as cobalt sensitivity plays a part in hard metal asthma.
\end{abstract}

Hard metal is an alloy of tungsten carbide in a matrix of cobalt and sometimes nickel in addition. Hard metal dust has been known to be associated with occupational asthma since Bruckner $^{1}$ first reported the development of asthma in a patient working in a tungsten carbide plant. Cobalt has been considered to be the factor responsible. ${ }^{2-12}$ Tungsten has been regarded as inert because it failed to provoke asthma in challenge tests. ${ }^{1011}$ Further support for sensitivity to cobalt came from our own studies, ${ }^{67}$ in which a positive result in the Farr test (precipitating antibody) with cobalt -57 was obtained from seven out of eight cobalt sensitive patients and in none of 60 non-exposed asthmatic patients. Cobalt has been thought to be the only causative agent in this disease. ${ }^{13}$ To be certain, however, bronchial challenge and immunoallergic studies need to be performed with other metal components, such as chromium and nickel, which are also known to cause occupational asthma, ${ }^{14}$ as these metals have been found in appreciable concentrations in open lung biopsy specimens, ${ }^{1015}$ bronchoalveolar lavage fluid, ${ }^{1015}$ and blood ${ }^{15}$ from workers exposed to hard metal dust.

The purpose of this study was to examine eight workers diagnosed as having hard metal asthma due to cobalt to assess the airway, skin and specific radioallergosorbent test (RAST) responses to nickel sulphate.
Methods

SUBJECTS (table 1)

Eight male workers (mean age 50 years) in a hard metal plant were diagnosed as having hard metal asthma on the basis of the following criteria $^{56}$ : (1) the development of wheezing, dyspnoea, and chest tightness at work or at home, or both, after starting work in the hard metal factory; (2) no symptoms at the weekend or during holidays and improvement in peak expiratory flow rate measurements at these times; (3) airflow obstruction that improved by over $15^{\circ}{ }_{0}$ after a bronchodilator; (4) no abnormality on the chest radiograph or computed tomogram; and (5) a positive bronchoprovocation response to cobalt chloride. Three of the patients worked in grinding, three in sintering, one in shaping, and one in the inspection department. Three had been transferred from the powder department to the less dusty sintering or inspection departments. None of the patients had a history of asthma before starting work in the plant.

We also studied eight non-smoking men (mean age 54 years). Three had atopic asthma and three non-atopic asthma, and two were normal volunteers. All had an $\mathrm{FEV}_{1}$ above $70^{\circ}$ \% predicted and underwent bronchial provocation tests and skin tests with nickel sulphate to verify that the metal solutions used in the challenge studies were not acting as nonspecific irritants. None of these patients had a history of exposure to hard metal dust.

\section{REAGENTS}

The test reagents were nickel sulphate (super special grade, Wako Pure Chemicals, Osaka) and methacholine chloride (Daiichi Pure Chemicals, Tokyo). High grade fraction V human serum albumin (HSA; Sigma, St Louis, Maryland) was dialysed against EDTA before use. Metal chemicals were diluted in phosphate buffered saline for skin tests and challenge studies. Methacholine chloride was diluted in physiological saline.

PERIPHERAL BLOOD ANALYSIS AND SEROLOGICAL STUDIES

Total and differential white blood cell counts, immunoglobulins (IgG, IgA, IgM), and complement levels were determined. Serum was collected from patients several days after they had been away from work, and from 25 symptomless male workers (five in shaping, 10 in sintering, and 10 in grinding) who had been exposed to hard metal dust in the same factory. Sixty control serum samples were also obtained from non-exposed patients with intrinsic and 
Table 1 Characteristics of patients and controls

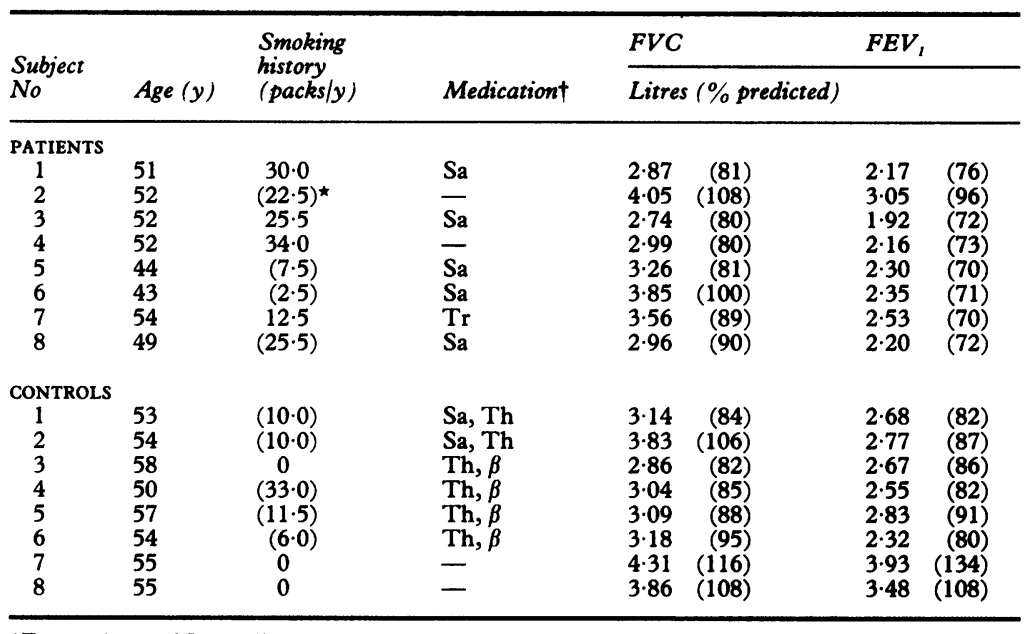

^Ex-smoker. †Sa-salbutamol inhaler; $\mathrm{Th}$-theophylline; $\mathrm{Tr}$-triamcinolone; $\boldsymbol{\beta}$-beta stimulant. FVC-forced vital capacity; $\mathrm{FEV}_{1}$-forced expiratory volume in one second.

extrinsic asthma. Control serum samples were divided into three groups according to their IgE titres: (1) low IgE ( $<400 \mathrm{IU} / \mathrm{ml})$, (2) high IgE (400-1000 IU $/ \mathrm{ml})$, and very high IgE ( $>1000 \mathrm{IU} / \mathrm{ml}$ ). Total serum IgE was determined by radioimmunosorbent assay with a Phadebas commercial kit (Shionogi, Osaka). Radioallergosorbent antibody titres were measured against 21 common and indigenous antigens (Phadebas, Sweden) and scored according to the Phadebas reference. A score of more than 2.0 was considered positive.

The modified RAST with nickel conjugated human serum albumin (Ni-HSA) was carried out as recommended by Malo et al. ${ }^{16}$ RAST scores were calculated by dividing the counts per minute (cpm) obtained from the test serum samples incubated with $\mathrm{Ni}-\mathrm{HSA}$ by the cpm obtained from the test serum incubated with nickel conjugated albumin. A score of more than 2.0 was considered positive. ${ }^{18}$ All the tests were done three times on the same subject.

SKIN TESTS

Serial tenfold dilutions from $10^{-5} \%$ to $1.0 \%$ and $2 \%$ nickel sulphate were used for intra- dermal skin tests. The results were recorded 15 minutes after injection. A weal more than $9 \mathrm{~mm}$ in diameter in the patients but not in the control subjects was regarded as a positive result. Patch tests were done with $2 \%$ nickel sulphate in petrolatum with readings taken after 48 and 72 hours. The response was measured by two dermatologists according to the classification recommended by the International Contact Dermatitis Research Group. ${ }^{19}$

\section{CHALLENGE STUDIES}

Bronchial provocation tests were performed as described previously. ${ }^{6}$ All medication was withheld from all subjects for five days before testing (no patient used antihistamine or antiallergic drugs). In patient 7 tests were performed a month after the last injection of triamcinolone (table 1). Baseline lung function was measured on the third day in hospital; challenge tests were performed only when the $\mathrm{FEV}_{1}$ was more than $70 \%$ predicted. Spirometry was performed with a rolling seal type spirometer (Chest, Tokyo). Solutions were administered via a DeVilbiss Type 646 nebuliser attached to a Rosenthal dosimeter. ${ }^{20}$ Serial 10 fold dilutions of nickel sulphate from $10^{-5} \%$ to $1.0 \%$ and $2.0 \%$ were administered. As the metal solutions were blue, the nebuliser and vials were covered with black tape to hide the colour of the solution. We confirmed that the $\mathrm{FEV}_{1}$ fell by less than $10 \%$ after inhalation of $0.9 \%$ normal saline by measuring $\mathrm{FEV}_{1}$ every 30 minutes for six hours on the fourth day in hospital. On the following day provocation tests were initiated with a concentration one tenth of that causing the first detectable response in the intradermal skin tests. If there was no skin response the inhalation tests were started with $10^{-5} \%$ of each solution to avoid unexpected severe reactions. Spirometry was performed every five minutes for 15 minutes after inhalation of each solution. If there was no positive reaction the subject inhaled a solution 10 times stronger. The challenge test was stopped when the FEV , had fallen by more than $20 \%$ or when $2 \%$ nickel sulphate had been

Table 2 Summary of results

\begin{tabular}{|c|c|c|c|c|c|c|c|}
\hline \multirow[b]{2}{*}{$\begin{array}{l}\text { Subject } \\
\text { No }\end{array}$} & \multirow[b]{2}{*}{$\begin{array}{l}\text { Total IgE } \\
(I U / \mathrm{ml})\end{array}$} & \multirow[b]{2}{*}{ Atopy ${ }^{\star}$} & \multirow[b]{2}{*}{$\begin{array}{l}\text { Eosinophils } \\
\left(\times 10^{9} / l\right)\end{array}$} & \multicolumn{4}{|l|}{ Cobalt $(\mathrm{Co}) \dagger$} \\
\hline & & & & Challenge test & Skin test $\ddagger$ & Patch test $\ddagger$ & $\begin{array}{l}\text { Co-HSA } \\
R A S T\end{array}$ \\
\hline \multicolumn{8}{|c|}{ PATIENTS } \\
\hline 1 & 217 & No & 87 & Late & $(+)$ & $(-)$ & Yes \\
\hline 2 & 73 & No & 252 & Late & $(-)$ & $(-)$ & No \\
\hline 3 & 1028 & Yes & 195 & Dual & $(+)$ & $(-)$ & No \\
\hline 4 & 231 & No & 288 & Immediate & $(-)$ & $(-)$ & No \\
\hline 5 & $\begin{array}{l}618 \\
588\end{array}$ & Yes & 616 & Dual & $(+)$ & $(+)$ & Yes \\
\hline $\begin{array}{l}6 \\
7\end{array}$ & $\begin{array}{l}588 \\
389\end{array}$ & $\begin{array}{l}\text { Yes } \\
\text { Yes }\end{array}$ & $\begin{array}{l}150 \\
129\end{array}$ & $\begin{array}{l}\text { Late } \\
\text { Immediate }\end{array}$ & $\begin{array}{l}(+) \\
(+)\end{array}$ & $\begin{array}{l}(-) \\
(+)\end{array}$ & $\begin{array}{l}\text { Yes } \\
\text { Yes }\end{array}$ \\
\hline 8 & 129 & No & 129 & Immediate & $(+)$ & $(+)$ & Yes \\
\hline \multicolumn{8}{|c|}{ CONTROLS } \\
\hline 1 & 2282 & Yes & 210 & NR & $(-)$ & $(-)$ & No \\
\hline 2 & 1813 & Yes & 512 & NR & $(-)$ & $(-)$ & No \\
\hline 3 & 1060 & Yes & 220 & NR & $(-)$ & $(-)$ & No \\
\hline 4 & 217 & No & 87 & NR & $(-)$ & $(-)$ & No \\
\hline 5 & 216 & No & 252 & NR & $(-)$ & $(-)$ & No \\
\hline 6 & 386 & No & 212 & NR & $(-)$ & $(-)$ & No \\
\hline 7 & 216 & No & 62 & NR & $(-)$ & $(-)$ & No \\
\hline 8 & 28 & No & 14 & NR & $(-)$ & $(-)$ & No \\
\hline
\end{tabular}

*More than three positive RAST scores for 21 allergens or high IgE titre or both.

+ See reference 6 .

+ See reference 6 .

++ indicates positi 
Figure 1 Scores for radioallergosorbent tests (RAST) with serum albumin ( $H S A$ ) and nickel conjugated albumin (Ni-HSA) in eight subjects with hard metal asthma, eight control subjects, 25 workers without symptoms, and 60 asthmatic patients without exposure to hard metal dust. $A$ positive score $(2.0$ or more) was seen by four of the subjects with hard metal asthma only; the others had negative scores. Vertical bars denote $2 S D$ in control subjects. Low IgE titre; $\mathbf{1}$ high IgE titre; $\Delta$ extra high IgE titre.

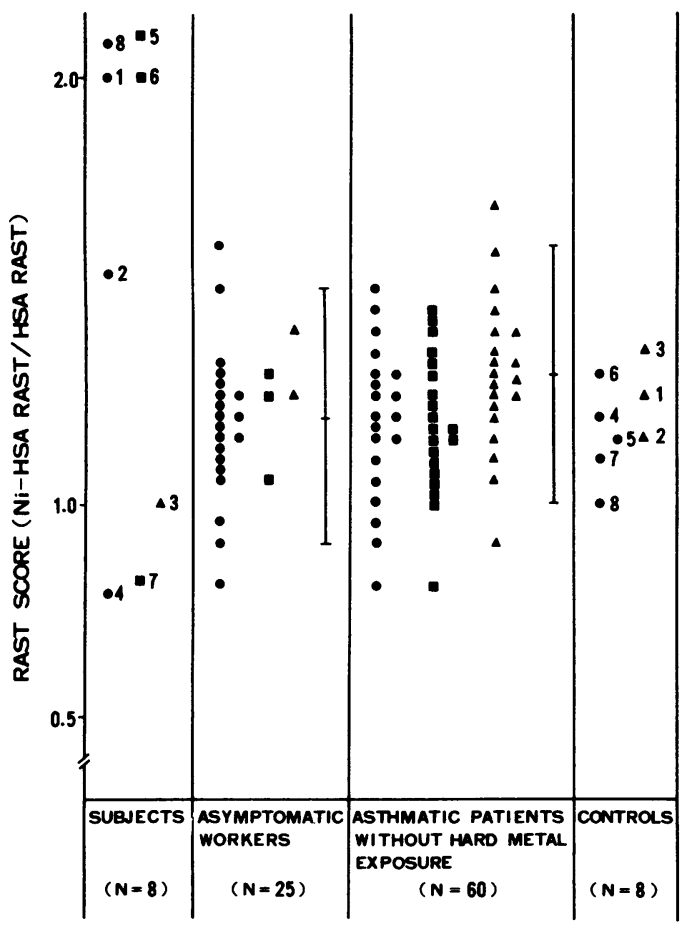

inhaled. Spirometry was measured every 30 minutes for six hours after the end of the study even when there had been no immediate response to $2^{\circ}{ }_{0}$ nickel sulphate. The reaction patterns were divided into three groups according to our previous results with cobalt chloride $^{6}$ : (1) early (onset within 20 minutes of challenge; (2) late (onset more than 30 minutes after challenge); and (3) dual (combination of 1 and 2).

A methacholine challenge test was performed before and on the day after nickel sulphate challenge, a modification of the method described by Hargreave et al being used. ${ }^{2}$ Methacholine was administered in increasing doubling doses from 0.038 to $25 \mu \mathrm{g} / \mathrm{ml}$ via a DeVilbiss Type 646 nebuliser at a flow rate of 5 $1 / \mathrm{min}$ (output $0.13 \mathrm{mg} / \mathrm{min}$ ). ${ }^{22}$ Patients inhaled each concentration for two minutes and FEV was recorded 30 and 90 seconds after each inhalation. The provocative concentration of methacholine causing a $20^{\circ}$ fall in $\mathrm{FEV}_{1}\left(\mathrm{PC}_{20}\right.$ methacholine) was calculated.

\begin{tabular}{|c|c|c|c|c|c|}
\hline \multicolumn{4}{|l|}{ Nickel (Ni) } & \multicolumn{2}{|c|}{$P C_{20}$ method $(\mu g / m l)$} \\
\hline Challenge test & Skin test $\ddagger$ & Patch test $\ddagger$ & Ni-HSA RAST & Before & After \\
\hline Late & $(+)$ & $(-)$ & Yes & 38 & 50 \\
\hline Immediate & $(-)$ & $(-)$ & No & 528 & 540 \\
\hline $14.5^{\circ}$ ", in $\mathrm{FEV} \mathrm{V}_{1}$ & $(-)$ & $(-)$ & No & 121 & 130 \\
\hline Late & $(-)$ & $(-)$ & No & $>25000$ & $>25000$ \\
\hline Immediate & $(+)$ & $(+)$ & Yes & 32 & 22 \\
\hline Late & $(+)$ & $(-)$ & Yes & 410 & 36 \\
\hline Immediate & $(+)$ & $(-)$ & No & 150 & 120 \\
\hline Immediate & $(+)$ & $(+)$ & Yes & 150 & 122 \\
\hline NR & $(-)$ & $(-)$ & No & 1125 & 1205 \\
\hline NR & $(-)$ & $(-)$ & No & 1260 & 1130 \\
\hline NR & $(-)$ & $(-)$ & No & 68 & 65 \\
\hline NR & $(-)$ & $(-)$ & No & 104 & 112 \\
\hline NR & $(-)$ & $(-)$ & No & 735 & 788 \\
\hline NR & $(-)$ & $(-)$ & No & 1140 & 1208 \\
\hline NR & $(-)$ & $(-)$ & No & $>25000$ & $>25000$ \\
\hline NR & $(-)$ & $(-)$ & No & $>25000$ & $>25000$ \\
\hline
\end{tabular}

Results

None of the subjects had hyperglobulinaemia or abnormal complement levels. Four patients and three control subjects were considered to be atopic on the basis of having more than three positive RAST scores, a total serum IgE titre above $400 \mathrm{IU} / \mathrm{ml}$ (one was 389: table 2), or a high eosinophil count $\left(>2.0 \times 10^{9} / 1\right)$. Four patients had raised Ni-HSA RAST scores $(>2.0)$; the remaining four subjects had mean scores $(0 \cdot 78-1.58)$ similar to those in the eight control subjects, .25 symptomless workers, and 60 asthmatic patients (fig 1). The mean HSA RAST count in the patients $(350 \mathrm{cpm})$ was very similar to that of the control subjects (361 $\mathrm{cpm})$. There was a strong correlation $(\mathrm{r}=0.81$, $\mathrm{p}<0.01$ ) between Ni-HSA counts and the mean diameter of the skin test weals produced by $1^{\circ}$ onickel sulphate in the eight patients. The results suggest that the serum from these four subjects contained IgE antibody specific to nickel that was $\mathrm{Ni}-\mathrm{HSA}$ dependent.

SKIN TESTS

Five of the eight patients had a positive reaction to $1^{\circ}$ o intradermal nickel sulphate and two other subjects to $2^{\circ}{ }_{0}$ nickel sulphate; none of the control subjects responded to $2 \%$ nickel sulphate. No late skin reactions were observed. The nickel sulphate patch test produced a reaction in two patients and none of the control subjects.

\section{CHALLENGE STUDIES}

Seven patients developed a fall in $\mathrm{FEV}_{1}$ of $20 \%$ or more in response to nickel sulphate (fig 2). Four patients developed an early response, and three a late response. Patient 3 did not develop bronchoconstriction after inhalation of $2 \%$ nickel sulphate.

The eight patients and eight control subjects showed various levels of bronchial responsiveness to methacholine. There was no change in the $\mathrm{PC}_{20}$ methacholine value 24 hours after inhalation of $2^{\circ}{ }_{0}$ nickel sulphate in any of the patients with an early reaction to nickel sulphate (though two received corticosteroids after the early reaction). There was a large fall in $\mathrm{PC}_{20}$ (from 410 to $36 \mu \mathrm{g} / \mathrm{ml}$ ) in patient 6 , who had a late reaction (fig 2 ).

\section{Discussion}

Nickel is sometimes added to hard metal as a matrix in addition to cobalt. Personal sampling has shown considerable amounts of nickel in the breathing zones (mean concentration 4.2$25.5 \mu \mathrm{g} / \mathrm{m}^{3}$ ). This concentration would be expected to increase the risk of occupational asthma as well as interstitial lung fibrosis from nickel and cobalt among hard metal workers.

Seven patients developed a positive bronchial reaction after inhaling $1 \%$ or $2 \%$ nickel sulphate (four early and three late reactions but no dual reactions); in patient $3 \mathrm{FEV}_{1}$ fell by $14 \%$ from the baseline value. A large change in $\mathrm{PC}_{20}$ methacholine was found in only one patient, who had a late reaction and a prolonged decrease in $\mathrm{FEV}_{1}$. An increase in bronchial responsiveness has occurred in late asthmatic 
reactions after inhalation of low molecular weight substances ( $<1000$ daltons). ${ }^{616}$ Only five cases of nickel asthma 1416172324 with bronchial challenge tests with nickel sulphate or work dust have been reported; two showed an early reaction, two a late reaction, and one a dual reaction. In the last case ${ }^{14}$ the worker was exposed to both nickel and chromium in a metal plating plant; whether nickel alone can induce a dual asthmatic reaction is therefore uncertain. A non-specific effect of nickel appears to be unlikely, since our eight control subjects, including six asthmatic patients with bronchial hyperresponsiveness, did not respond to inhalation of $2 \%$ nickel sulphate.

Further evidence for sensitisation to nickel comes from the finding of nickel reactive IgE antibodies in four of our affected patients (mean (SD) RAST index 2.08 (0.08)) and absence of these specific antibodies in the serum from 60 non-exposed asthmatic patients $(1.42(0 \cdot 15))$ and 25 symptomless exposed workers $(1.32(0 \cdot 16))$ with a wide range of serum IgE titres (fig 1). The standard deviation for the RAST results in the three groups was small, indicating good reproducibility of the test in both patients (SD 0.08) and control subjects $(0.06)$. Furthermore, there was a strong correlation $(r=0.81)$ between the mean diameters of the weals produced by intradermal nickel sulphate and Ni-HSA RAST. The absence of specific antibodies in the serum from the other patients with hard metal asthma was not unexpected because skin reactivity does not always correspond to specific RAST scores. ${ }^{16}$ These findings suggest that nickel may have some role in hard metal asthma through a type I as well as a non-immunological mechanism.

Four patients showed evidence of specific IgE antibodies to cobalt conjugated albumin and nickel conjugated albumin (table 2), indicating that there may be some cross or

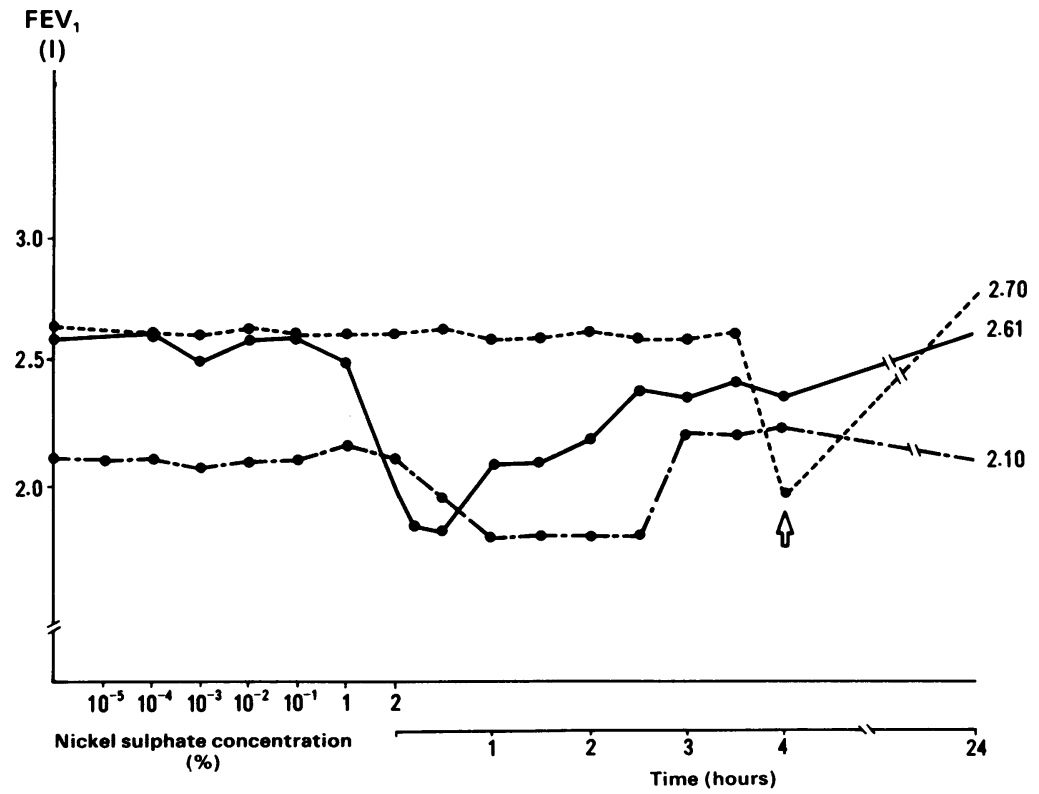

Figure 2 Results of inhalation challenge with nickel sulphate $\left(\mathrm{NiSO}_{4}\right)$. Three types of reaction pattern were found after inhalation of cumulative doses of nickel sulphate: immediate response (case $7: 0-0$ ), late response (case 1: - - , and negative immediate response (case 7: - -1 ), late response (case $1: 0-1 .-0$ ), and negative
response (case 3: indicates the time when a salbutamol inhaler was given. concomitant reactivity between cobalt and nickel among sensitised workers in the development of hard metal asthma. Only one report, however, has been published on sensitisation to two heavy metals as a cause of asthma. ${ }^{14}$ Many workers with occupational asthma are exposed to more than one possible inducing agent, and the question arises of whether interactions between agents are occurring. A possible clue to a pathological interaction between cobalt and nickel may be seen in earpiece dermatitis ${ }^{25} 26$ and hard metal dermatitis, ${ }^{27}$ in which a type IV allergic reaction between metals has been found. ${ }^{29}{ }^{30}$ Our patch test result showed a simultaneous reaction to two metals in patients 5 and 8 (table 2). Denatured proteins induced by heavy metals may result in complexes that are so similar that immunocompetent cells can not distinguish them. These findings raise the possibility of concomitant or cross reactive type $I$ as well as type IV allergic reactions between cobalt and nickel in sensitised workers with hard metal asthma. It is not clear from the present study whether an immunological basis, established in nickel asthma, ${ }^{31}{ }^{32}$ applies to patients with both nickel and cobalt sensitivities due to hard metal exposure.

We thank Mr O Tani and Mrs $M$ Nishigichi (Takatsuki Red Cross Hospital) for their assistance with the radioallergosorbent assay.

1 Bruckner HC. Extrinsic asthma in a tungsten carbide worker. J Occup Med 1967;9:518-9.

2 Hartmann A, Wuthrich B, Bolognini G. Berufsbendingte lungenkrankheiten bei der Hartmetallproducktion und Bearbeitung ein allergisches Geschehen? Schweiz Med Wochenschr 1982;112:1137-41.

3 Sjogren I, Hillerdal G, Andersson A, Zetterstroem O. Hard metal disease; importance of cobalt in coolants. Thorax 1980;36:653-9.

4 Roto P. Asthmas, symptoms of chronic bronchitis and ventilatory capacity among cobalt and zinc production vorkers. Scand J Work Environ Health 1979;6(suppl): $1-49$.

5 Kusaka Y, Yokoyama K, Sera Y, et al. Respiratory diseases in hard metal workers: an occupational hygienic study in a factory. Br J Ind Med 1986;43:474-85.

6 Shirakawa T, Kusaka Y, Fujimura N, et al. Occupational asthma from cobalt sensitivity in workers exposed to hard metal dust. Chest 1989;95:29-37.

7 Shirakawa T, Kusaka Y, Fujimura N, Morimoto K. The existence of specific antibodies to cobalt in hard metal asthma. Clin Allergy 1988;18:451-60.

8 Demedts $M$, Gheysens B, Nagels J, et al. Cobalt lung in diamond polishers. Am Rev Respir Dis 1984;130:130-5.

9 Gheysens B, Auwerxs J, Van den Eekhout, Demedts M. Cobalt induced bronchial asthma in diamond polishers. Chest $1986 ; 88: 740-4$

10 Coates EO, Sawyer HJ, Rebeck JW, Kvale LW. Hypersensitivity pneumonitis in tungsten carbide workers. Chest 1973;64:390.

11 Davison AG, Haslam PL, Corrin B, et al. Interstitial lung disease: bronchoalveolar lavage, ultrastructural and analytical findings, and results of bronchial provocation tests. Thorax 1983;38:119-28.

12 Schepers GWH. The biological action of particular cobalt metal, tantalum oxide, cobalt oxide, tungsten metal, tungsten carbide and cobalt. Arch Ind Health 1955; 12:140-6.

13 Cullen MR. Respiratory diseases from hard metal exposure. A continuous enigma. Chest 1984;86:513-4.

14 Novey HS, Habib M, Wells ID. Asthma and IgE antibodies induced by chromium and nickel salts. $J$ Allergy Clin induced by chromium and

15 Rizzato G, Lo Cicero S, Barberis M, Torre M, Pietra R, Sabbioni $E$. Trace of metal exposure in hard metal lung Sabbioni E. Trace of metal expo
disease. Chest 1986;90:101-6.

16 Malo JL, Cartier A, Doepner M, Nieboer E, Evans S, Dolovich J. Occupational asthma caused by nickel sulfate. Dolovich J. Occupational asthma caused

17 Malo JL, Cartier A, Gagnon G, Evans S, Dolovich J. Malo JL, Cartier A, Gagnon G, Evans S, Dolovich J.
Isolated late asthmatic reaction due to nickel antibody. Clin Allergy 1985;15:95-9.

8 Butcher BT, O'Neil CE, Reed MA, Salvaggio JE. Radioallergosorbent testing of toluene diisocyanate-reactive individuals using p-tolyl isocyanate antigen. J Allergy Clin 
Immunol 1980;66:213-6.

19 Fregert S, Bandmann HJ. Patch test. Berlin: Springer, 1975:24.

20 Rosenthal RR. Inhalation challenge: procedure, indication techniques. The emerging role of bronchoprovocation. J Allergy Clin Immunol 1979;64:564-8.

21 Hargreave FE, Ryan G, Thomson NC, et al. Bronchial responsiveness to histamine and methacholine in asthma; measurement and clinical significance. J Allergy Clin Immunol 1981;67:347-55.

22 Ryan G, Dolovich J, Obminski G, et al. Standardization of inhalation provocation tests; influence of nebulizer output, particle size and method of inhalation. J Allergy Clin Immunol 1981;67:156-61.

23 Block JT, Yeung $M$. Asthma induced by nickel. JAMA 1982;247:1600-2.

24 Davies JE. Occupational asthma caused by nickel salts. $J$ Soc Occ Med 1986;36:29-31.

25 Gaul LE. Development of allergic nickel dermatitis from earring. JAMA 1967;200:176.

26 Menne T. Relationship between nickel and cobalt sensitization in female. Contact Dermatitis 1980;6:337.

27 Fisher T, Rystedt I. Cobalt allergy in hard metal workers. Contact Dermatitis 1983;9:115-21.

28 Rystedt I, Fisher T. Relationship between nickel and cobalt in hard metal workers. Contact Dermatitis 1983;9: in hard

29 Fregert S, Rosman H. Allergy to chromium, nickel and cobalt. Acta Dermato-Venereol 1966;46:144-8.

30 Venezia C, Karol MH. Comparison of cobalt and chromium binding to blood elements. Toxicology 1984;30:125-33.

31 Dolovich J, Evans S, Nieboer E. Occupational asthma from nickel sensitivity. I-Human serum albumin in the antigenic determinant. Br J Ind Med 1984;41:51-5.

32 Nieboer E, Evans SL, Dolovich J. Occupational asthma from nickel sensitivity. II-Factors influencing the nickel related specificity. Br J Ind Med 1984;41:56-63. 